УДК 633.11, DOI 10.31210/visnyk2018.04.10

(C) 2018

Семенов А. О., кандидат фізико-математичних наук,

Бургу Ю. Г., кандидат сільськогосподарських наук,

Кожушко Г. М., доктор технічних наук

Полтавський університет економіки і торгівлі

Маренич М. М., кандидат сільськогосподарських наук, Сахно Т. В., доктор хімічних наук

Полтавська державна аграрна академія

\title{
ВПЛИВ УЛЬТРАФІОЛЕТОВОГО ВИПРОМІНЮВАННЯ НА ПРОРОСТАННЯ, СХОЖІСТЬ ТА РОСТОВІ ПРОЦЕСИ НАСІННЯ ПШЕНИЦ
}

\section{Рецензент - доктор сільськогосподарських наук Г. О. Бірта}

\begin{abstract}
Досліджено передпосівний вплив ультрафіолетового (УФ) опромінення насіння пшенииі озимої м'якої на посівні властивості (енергія проростання та схожість). В якості джерел УФ-опромінення використовували ультрафіолетові лампи низького тиску, щчо випромінюють в області С. Насіння пшениці сортів Подолянка, Тарас, Астра та Южанка опроміню-

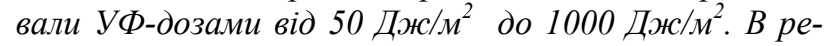
зультаті експериментальних досліджень встановлено, що оптимальними дозами ультрафіолетового опромінювання в області С для даних сортів пшениці є дози 400-600 Дж/м². Енергія проростання для досліджених зразків пшениці після УФ-опромінення збільшилася на 7-12\%, а-схожість на 9-15\%. Довжина коренів збільшилася на 11-40\%, а наземна частина - на $13-25 \%$.
\end{abstract}

Ключові слова: УФ-опромінення, передпосівна обробка насіння, доза опромінення, енергія проростання, схожість насіння пшениці.

Постановка проблеми. Збільшення кількості та якості продукції рослинництва - головна задача розвитку сільськогосподарського комплексу, де якості посівного матеріалу надається одна 3 ключових ролей.

Вчені та фахівці сільського господарства постійно вдосконалюють і розробляють нові агрозаходи і технічні засоби для передпосівної обробки насіння 3 метою стимуляції проростання $[1$, $9,10]$.

Забезпечення високої врожайності культури за оптимальних затрат та високоякісних показників насіння, а також освоєння технологій отримання нових видів продукції - важливі завдання агропромислового комплексу на найближчу перспективу.

Тому актуальність роботи визначається пошуком та освоєнням технологій отримання ефективних фізичних біостимуляторів для передпосівної обробки насіння [16], що підвищують продуктивність сільськогосподарських культур.
Аналіз останніх досліджень i публікацій, у яких започатковано розв'язання проблеми. $€$ безліч робіт, присвячених впливу на насіннєвий матеріал фізичних факторів, які сприяють підвищенню посівних якостей, посиленню фотосинтетичної активності, виживанню і врожайності [25].

До фізичних факторів впливу на посівний матеріал можна віднести електромагнітні поля різних діапазонів (від $\gamma$-випромінювання до радіочастотного дециметрового діапазону [28]), рентгенівське випромінювання [3], ультрафіолетове [15] і оптичне випромінювання (особливо лазерне червоне випромінювання з $\lambda=632,8$ нм [2]), інфрачервоне випромінювання [4], електричне поле коронного розряду, ультразвукова дія [27], дія магнітного поля [26]. Відомими є дослідження, в яких вплив слабких фізичних факторів призводив до стимуляції врожайності і підвищення якості продукції [25].

В останні роки 3 метою інтенсифікації рослинництва в практику сільського господарства стали активно впроваджувати електрофізичні методи обробки рослин та насіння зернових, овочевих культур $[7,9,16]$. Застосовуючи електромагнітний вплив різної частоти, можливо отримати прибавку врожаю на 10-12 \%, знищити насіннєву інфекцію, збільшити енергію проростання і схожість насіння [24]. В роботі [7] наводяться дані, що в разі обробки електромагнітним полем високої частоти (ЕМП НВЧ) підвищується біологічна цінність зерна пшениці за рахунок збільшення вмісту деяких водорозчинних вітамінів. У дослідженнях на зернових, овочевих, кормових культурах було виявлено, що короткочасний вплив високовольтного коронного розряду призводить до прискорення проростання насіння як в лабораторних, так і в польових умовах. Вважається, що в основному на енергію проростання і підвищення польової схожості насіння за такої обробки позитивно впливає 


\section{СІЛЬСЬКЕ ГОСПОДАРСТВО. РОСЛИННИЦТВО}

їх поверхневе знезараження, яке обмежує поширення і ступінь розвитку борошнистої роси, бурої іржі, кореневих гнилей та інших хвороб. Ефективність електромагнітного впливу залежить від частоти імпульсів і часу опромінення насіння [9].

У статті [5] представлено результати застосування лазерної технології обробки насіння пшениці. За оптимальних середніх доз опромінення:

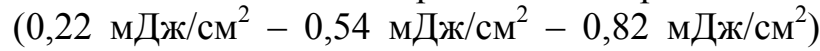
лазерна передпосівна обробка насіння довжиною хвилі $\lambda=650$ нм сприяє суттєвому підвищенню врожайності пшениці сорту Іргіна.

У роботі [6] відзначено перевагу впливу передпосівної обробки насіння зеленим лазерним випромінюванням у порівнянні 3 синім і червоним лазерним випромінюванням, що впливає на ріст кореневої системи і надземної частини пшениці.

Ефективність застосування електротеплового випромінювання в технологічному процесі передпосівної обробки насіння пшениці була показана авторами [23]. Аналіз результатів лабораторних і польових досліджень 3 часом обробки 5 секунд (при температур 45 i $50{ }^{0} \mathrm{C}$ ) та 3 часом обробки 3 секунди (при температурі 50 і $55{ }^{0} \mathrm{C}$ ) показує збільшення лабораторної схожості насіння пшениці щодо контрольних зразків за всіх режимів обробки на $25,4 \div 54,5 \%$. Крім того, зараженість досліджуваних зразків фітопатогенами знизилася до 66,6-87,5 \%, а збудниками пліснявіння - до 90,9\%.

Значне число експериментальних робіт присвячено УФ-опроміненню посівного матеріалу. Відзначено високу чутливість рослин до умов опромінення [8, 15, 18, 20].

$\mathrm{y}$ роботі [8] зерна пшениці опромінювали в передпосівний період під час переміщення на стрічці транспортеру. Зерно піддавалось УФопроміненню ртутно-кварцовою лампою БНП02-30-001У3,5 (пристрій спектр-2) 3 інтенсивністю енергетичного опромінення $30 \mathrm{BT} / \mathrm{m}^{2}$, що розташовувалася на відстані 25 см від об'єкта. Зниження вільнорадикальних процесів у насінні можливо за рахунок синтезу великої кількості антиоксидантів, концентрація яких при цьому зростає в кілька разів, особливо в зародку насіння пшениці, тобто відзначається активація антиоксидантної системи у відповідь на УФ-опромінення.

У роботі [14] розглянуто закономірності прояву активності пероксидази в процесі набухання i проростання насіння пшениці (Triticum aestivum L.) сорту Ростовчанка 5 та показників перекисного окислення ліпідів у проростках пшениці після опромінення УФ джерелом у тих же умо- вах, що і в роботі [8]. Обрані режими опромінення протягом 5 і 60 хвилин у ході експерименту дали змогу встановити, що саме варіант тривалого ультрафіолетового опромінювання насіння протягом 60 хвилин підвищує їх схожість на $12-15 \%$.

Автори роботи [21] вивчали вплив ультрафіолетового опромінення від джерела VL-6.LC 3 довжиною хвилі 365 нм протягом 5 і 30 хвилин на насіння ярої та озимої пшениці різних сортів. Маса проростків пшениці після 30 хвилин опромінення збільшується у всіх сортів: для сортів «Московська 39» і «Ювілейна 100» приріст склав 20 \%. У всіх досліджуваних сортів пшениці, за винятком сорту «Дарина», істотно збільшилася довжина коренів - на 26-60 \%. Автори під час дослідження впливу ультрафіолетового випромінювання на посівні якості насіння і біометричні показники рослин різних сільгоспкультур встановили, що дія УФ-випромінювання вибіркова - для насіння кожного сорту існує своя оптимальна кількість поглиненої енергії.

Не дивлячись на велику кількість досліджень $[8,14,15,18,20,21]$, питання щодо визначення раціонального діапазону доз опромінення різних культур, у тому числі різних сортів пшениці, продовжує залишатися актуальним.

Мета роботи - дослідження впливу передпосівного ультрафіолетового опромінення насіння пшениці озимої на біологічні процеси (енергія проростання, схожість та зростання).

Задача дослідження - встановити ефективність впливу передпосівного УФ-опромінення в області $\mathrm{C}$ із визначенням необхідних доз ультрафіолетового опромінення на енергію проростання, схожість та зростання насіння озимої пшениці різних сортів у лабораторних умовах.

Енергія проростання насіння $є$ важливим показником якості посівного матеріалу. Вона характеризує ступінь життєздатності насіння, здатність давати швидкі й дружні сходи, що має велике значення для одержання високого врожаю.

Лабораторна схожість насіння - кількісний показник його якості, який є мірилом життєздатності. У насіння з пониженою схожістю різко погіршуються врожайні властивості і досить часто, навіть зі збільшенням норми висіву, неможливо досягти високого врожаю.

Матеріали та умови проведення досліджень. Енергію проростання та схожість насіння пшениці визначали в лабораторних умовах за методикою згідно 3 [12].

Отримані показники для насіння опроміненого різними дозами УФ-С порівнювали з контрольними зразками (без опромінення). 


\section{СІЛЬСЬКЕ ГОСПОДАРСТВО. РОСЛИННИЦТВО}

Зразки пшениці м’якої озимої для проведення дослідження представлені лабораторією зернових культур Устимівської дослідної станції рослинництва.

Для проведення дослідів було відраховано 200 насінин для контрольного зразку та по 200 зернин для опромінення дозами: 50 Дж/м²;

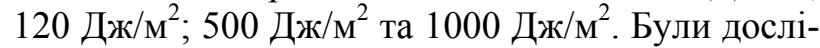
джені зразки: № 1 - Подолянка (UDS02111); № 2 - Tapac (UDS05054); № 3 - Астра (UDS04766) та № 4 - Южанка (UDS04779) врожаю 2018 року.

Насіння розкладались на кількох шарах зволоженого фільтрувального паперу в чашках Петрі і витримувались в термостаті за температури $7 \pm 2{ }^{0} \mathrm{C}$ протягом доби. Далі охолоджені зразки (крім контрольних) опромінювали УФ-С дозами 3 використанням безозонових кварцових ультрафіолетових ламп [19].

Для опромінення застосовували УФ лампу типу ZW20D15W потужністю 20 Вт [17]. Відстань від лампи до зразків насіння становила 0,25 м. Вимірювання дози УФ-С випромінювання здійснювали за допомогою радіометра «Тензор-31» 3 використанням методики [11].

Опромінені і контрольні зразки насіння пророщували в чашках Петрі за температури повітря $24 \pm 2{ }^{0} \mathrm{C}$. Перший облік проростків насіння (енергія проростання) проводили через 4 доби, а відсоток схожості - через 8 діб.
Результати досліджень. У лабораторних умовах проведені дослідження з визначення енергії проростання та схожості насіння пшениці [13] після УФ-опромінення різними дозами:

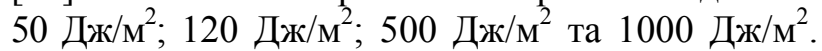
Результати дослідження наведео на рис. 1 та зведено в табл. 1 та 2.

3 представленої залежності (рис. 1) енергії проростання від дози ультрафіолетового опромінення визначили, що оптимальними дозами для опромінення насіння пшениці $€$ дози 400-600 Дж/м², за яких кількість пророслого насіння $\epsilon$ максимальною. Дози, наближені до 1000 Дж/м² спричинили незначний спад показників дослідження (рис. 1).

Результати досліджень енергії проростання та схожості насіння пшениці різних сортів у випадку дози УФ-С опромінення 500 Дж/м² (табл. 1) показали, що енергія проростання збільшилася, в порівнянні з контрольними зразками, на 7$12 \%$, а схожість - на 9-14,6\%.

У позитивних результатах впливу УФ-опромінення на насіння пшениці під час визначення схожості відзначили й ефективніший розвиток кореневої системи і наземної частини.

При цьому збільшення кореневої системи для опромінених зразків (табл. 1) становила 11,6$39,8 \%$, а збільшення надземної частини $13,5-$ 24,7\% (табл. 2).

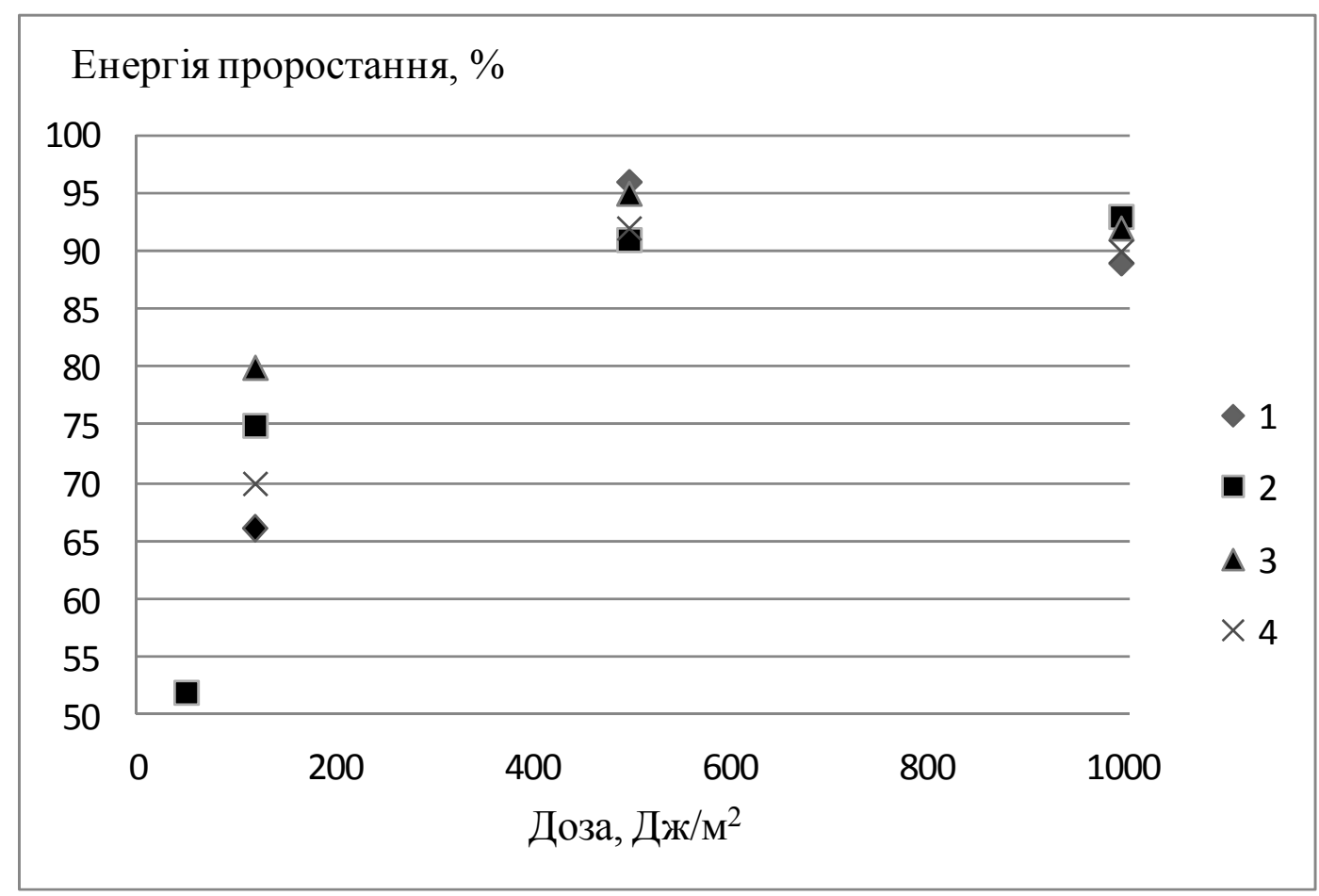

Рис. 1. Енергія проростання насіння пиениці після опромінення (зразки № 1, 2, 3, 4). 
СІЛЬСЬКЕ ГОСПОДАРСТВО. РОСЛИННИЦТВО

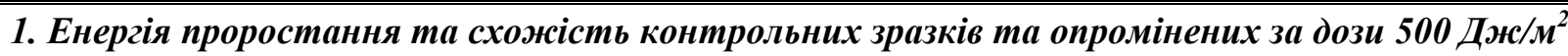

\begin{tabular}{|c|c|c|}
\hline Зразки & Енергія проростання, \% & Схожість, \% \\
\hline 1 - контрольний & 88 & 89 \\
1 - опромінений & 96 & 97 \\
\hline 2 - контрольний & 85 & 86 \\
2 - опромінений & 91 & 94 \\
\hline $3-$ контрольний & 86 & 88 \\
3 - опромінений & 95 & 86 \\
\hline $4-$ контрольний & 82 & 94 \\
\hline 4- опромінений & 92 & 82 \\
\hline
\end{tabular}

\section{2. Результати середніх значень довжини коренів та наземної частини}

\begin{tabular}{|c|c|c|}
\hline Зразки & Довжина коренів, мм & $\begin{array}{c}\text { Наземна частина (стебло), } \\
\text { мм }\end{array}$ \\
\hline 1 - контрольний & 38,7 & 109,3 \\
$1-$ опромінений & 43,2 & 124,1 \\
\hline $2-$ контрольний & 33,4 & 98,2 \\
$2-$ опромінений & 37,6 & 117,4 \\
\hline $3-$ контрольний & 42,1 & 114,1 \\
$3-$ опромінений & 46,3 & 121,2 \\
\hline $4-$ контрольний & 32,4 & 98,4 \\
$4-$ опромінений & 45,3 & 122,8 \\
\hline
\end{tabular}

Висновок. Оптимальною УФ-дозою в області С для сортів Подолянка, Тарас, Астра та Южанка $є$ доза 400-600 Дж/м². Енергія проростання для досліджених зразків після УФ-опромінення збільшилася на 7-12\%, а схожість - на 9-15\%. Довжина коренів збільшилася на 11-40\%, а наземна частина - на $13-25 \%$.

Передпосівна обробка насіння пшениці озимої

\section{БІБЛІОГРАФІЯ}

1. Алтухов И. В. Изменение основных качественных показателей семян пшеницы после воздействия различными облучателями / И. В. Алтухов, В. А. Федотов, В. Д. Очиров // Вестник ИрГСХА : сборник научных трудов. - Иркутск : ИрГСХА. - 2010. - Вып. 40. - С. 107-115.

2. Батян A. Н. Стимулирующий эффект лазерного излучения на начальные этапы онтогенеза пшеницы озимой / А. Н. Батян, В. А. Кравченко, А. П. Клюев, В. В. Литвяк, И. М. Почицкая // Экологический вестник. - 2017. - №2 (40). - С. 123-128.

3. Бессонова Л. А. Поглощение рентгеновского излучения оболочками семян пшеницы / Л. А. Бессонова, Э. А. Каменир // Физиология и биохимия культурных растений. - 1991. 23. - №6. - С. 582-588.

4. Гаджсимусиева Н. T. Эффект воздействия инфракрасного и лазерного излучения на всхожесть м'якої ультрафіолетовим опроміненням в Сдіапазоні може знайти практичне використання у разі вирощування рослин без використання стимуляторів росту, хімічних препаратів. Таким чином, можливе зменшення кількості пестицидів у передпосівній обробці насіння або повна відмова від їх використання в перспективі, як це вже тривалий час робиться в розвинених країнах.

семян пшеницы / Н. Т. Гаджимусиева, Т. А. Асварова, А. С. Абдулаева // Фундаментальные исследования. - 2014. - №11. - Ч. 9. - С. 1939-1943.

5. Долговых О. Г. Определение оптимального режима лазерной обработки семян яровой пшеницы Ирень / О. Г. Долговых, П. В. Дородов, Р. Р. Газтдинов // Аграрный вестник Урала : всеpoc. науч. аграрн. журн. - 2013. - №4. - С. 33-36.

6. Жукова Т. А. Влияние длины волны лазерного излучения на эффективность прорастания семян и формирование ростка пшеницы / Т. А. Жукова // Аграрная наука в условиях модернизации и инновационного развития. - 2017. - С. 82-84.

7. Кондратенко Е. П. Моделирование признаков посевных качеств семян пшеницы под влиянием электромагнитной обработки / Е. П. Кондратенко, О. М. Соболева, И. В. Егорова, Н. В. Вербицкая // Вестник Красноярского государственного аграр- 


\section{СІЛЬСЬКЕ ГОСПОДАРСТВО. РОСЛИННИЦТВО}

ного университета. - 2014. - №2. - С. 157-162.

8. Кондратьева Н. П. Перспективы использования электротехнологии для повышения посевных качеств семян УФ-излучением / Н. П. Кондратьева, В. Ю. Романов, М. Н. Чефранова, Т. В. Нуреева, Д. А. Корепанов, М. Г. Краснолуцкая, Р. Г. Большин // Известия Международной академии аграрного образования. - 2015. - №24. - С. 10-13.

9. Левина Н. С. Посевные качества семян мягкой яровой пшеницы (Triticum aestivum L.) при разных режимах воздействия низкочастотным электромагнитным полем / Н. С. Левина, Ю. В. Тертышная, И. А. Бидей, О. В. Елизарова, Л. С. Шибряева // Сельскохозяйственная биология. 2017. - T. 52. - №3. - С. 580-587.

10. Маренич М. М. Вплив допосівної обробки насіння біологічно активними речовинами на ріст і розвиток рослин пшениці озимої на початкових стадіях / М. М. Маренич, С. О. Юрченко // Вісник Полтавської державної аграрної академiї. - 2017. - №1-2. - С. 38-42.

11. МВУ 11-038-2007. Джерела ультрафіолетового випромінювання : методика виконання вимірювань параметрів ультрафіолетового випромінювання. Харків: ННЦ «Інститут метрологї̈ю. $-2007 .-33 \mathrm{c}$.

12. Насіння сільськогосподарських культур. Методи визначення якості : ДСТУ-4138-2002 [Чинний від 01-01-2004] - К. : Держспоживстандарт України, 2003. - 173 с. (Державний стандарт України).

13. Новак Ж. М. Схожість і енергія проростання зразків пшениці спельти / Ж. М. Новак, I. O. Полянецька // Збірник наукових праць Уманського національного університету садівництва. - 2016. - Вип. 88 (1). - С. 261-266.

14. Рогожин Ю. В. Технология предпосевного УФ-облучения зерен пшеницы / Ю. В. Рогожин, В. В. Рогожин // Вестник Алтайского государственного аграрного университета. - 2013. - №6 (104). - C. 9-14.

15. Савельев B. A. Обработка семян пшеницы ультрафиолетовыми лучами / В. А. Савельев // Вестник с.-х. науки. - 1990. - Вып. 3. - С. 133135.

16. Семенов А. О. Аналіз ролі УФ-випромінювання на розвиток і продуктивність різних культур / А. О. Семенов, Г. М. Кожушко, Т. В. Сахно // Світлотехніка та електроенергетика. 2017. - №2. - C. 3-16.

17. Семенов А. О. Безозонні бактерицидні лампи для установок фотохімічної і фотобіологічної дії / А. О. Семенов, Г. М. Кожушко, Л. В. Баля // Технологический аудит и резервы производства. - 2015. - №4/1 (24). - С. 4-7.
18. Семенов А.О. Вплив передпосівного УФопромінення насіння ріпаку на розвиток рослин / А. О. Семенов, Г. М. Кожушко, Т. В. Сахно / $\mathrm{V}$ Міжнародна науково-практична інтернет конференція «Сучасне матеріалознавство та товарознавство: теорія, практика, освіта». - Полтава, ПУЕТ. - 2018. - С. 105-109.

19. Семенов А. О. Особливості конструкції одноцокольних ламп для ультрафіолетового опромінення / А. О. Семенов // Scientific Journal «ScienceRise». - 2014. - C. 64-67.

20. Семенов А. О. Ефективність проростання насіння ріпаку при передпосівному опроміненні його УФ-випроміненням різного спектрального складу / А. О. Семенов, Г. М. Кожушко, Т. В. Сахно // Вісник Полтавської державної аграрної академії. - 2018. - №3. - С. 27-31.

21. Симонова Е. Н. Активность пероксидазы и показателей перекисного окисления липидов в прорастающих семенах озимой пшеницы после УФ-облучения / Е. Н. Симонова // Зерновое хозяйство России. - 2017. - №6 (2017). - С. 41-43.

22. Тертышная Ю. В. Воздействие ультрафиолетового излучения на всхожесть и ростовые процессы семян пшеницы / Ю. В. Тертышная, Н. С. Левина, О. В. Елизарова // Сельскохозяйственные машины и технологии. - 2017. - №2. - С. 31-36.

23. Федотов B. A. Влияние параметров электротеплового излучения на фитосанитарное состояние семян пшеницы // Инновации в сельском хозяйстве. $-2015 .-2$ (12). - С. 63-66.

24. Alicamanoglu S. Stimulation of growth and some biochemical parameters by magnetic field in wheat (Triticum aestivum L.) tissue cultures / S. Alicamanoglu, A. Sen // Afr. J. Biotechnol. 2011. - V. 53. - P. 10957-10963.

25. Araújo S. S. Physical Methods for Seed Invigoration: Advantages and Challenges in Seed Technology / S. S. Araújo, S. Paparella, D. Dondi, A. Bentivoglio, D. Carbonera, A. Balestrazzi // Front. Plant Sci. 2016. - V. 7. - P. 646.

26. Balakhnina T. The influence of wheat Triticum aestivum L. seed pre-sowing treatment with magnetic fields on germination, seedling growth, and antioxidant potential under optimal soil watering and flooding / T. Balakhnina, P. Bulak, M. Nosalewicz, S. Pietruszewski, T. Wlodarczyk // Acta Physiologiae Plantarum. - 2015. - V. 37. №3. - P. 59.

27. Goussous S. J. Enhancing seed germination of four crop species using an ultrasonic technique / S. J. Goussous, N. H. Samarah, A. M. Alqudah, M. O. Othman // Expl Agric. - 2010. - V. 46 (2). P. 231-242.

28. Sajjad Ahmed. Impact of gamma radiations on 
wheat (Triticum aestivum L.) varieties (Batoor and Janbaz) / Sajjad Ahmed, Wisal Muhammad Khan, Muhammad Saleem Khan, Naveed Akhtar, Nosheen

\section{ANNOTATION}

Semenov A. O., Burhu Yu. G., Kozhushko G. M., Marenych M. M., Sakhno T. V. Influence of ultraviolet radiation on germination, sprouting and growth processes of wheat.

One of the main task of the agro-industrial complex is to increase quantity and quality of crop production. Use of optical radiation that is preliminary treatment of seeds by ultraviolet radiation is of great interest to growth stimulation and increasing resistance of plants to external factors and improving productivity of crops.

Scientists and specialists of the agro-industrial complex investigating influence of ultraviolet radiation on seed sowing characteristics and biometric indices of plants of different crops highlight that the effect of ultraviolet radiation is selective and there is its own optimal amount of absorbed energy for seeds of each varity. The necessity for research is due to the uncertainty of the effect of UV radiation on the most crops, in particular wheat seeds.

Presowing effect of ultraviolet radiation of winter wheat seeds on sowing characteristics (sprouting energy, germination and development) has been investigated in the work. The first record
Umar, Sajjad Ali, Saddam Hussain and Syed Sadaqat Shah // Pure Appl. Biol. - 2017. - 6 (1). P. 218-225.

of seedlings (sprouting energy) was carried out in 4 days and the percentage of germination in 8 days.

Ultraviolet bulbs of low pressure emitting in the $\mathrm{C}$ area were used as UV radiation sources. Seed of wheat varieties Podolianka, Taras, Astra, and Yuzhanka were radiated with UV doses in the range from $50 \mathrm{~J} / \mathrm{m}^{2}$ to $1000 \mathrm{~J} / \mathrm{m}^{2}$. As a result of experimental studies it has been established that the optimal UV doses of ultraviolet radiation in the $\mathrm{C}$ area for these wheat varieties, in which the germination and sprouting energy have a maximum value, are in the range of $400-600 \mathrm{~J} / \mathrm{m}^{2}$.

Sprouting energy has increased by $7-12 \%$ and germination has increased by $9-15 \%$ as a result of UV radiation of wheat samples at doses of $500 \mathrm{~J} / \mathrm{m}^{2}$. The length of roots and the aboveground part was measured in order to determine percentage of wheat seeds germination. The length of roots has increased by $11-40 \%$ and the length of aboveground part has increased by $13-25 \%$.

Presowing processing of wheat seeds by UV radiation can be very useful for growing plants without growth stimulants application.

Key words: ultraviolet radiation, radiation dose, sprouting energy, germination. 